been compounded by the failure of courts to recognize that women are not solely dependents, but are also political actors in their own right. Crawley acknowledges that there has been some movement towards a recognition of certain groups of women as 'social groups' according to the 1951 Convention (for example the case of Shah Islam in Britain), but stresses the significance of the public/private divide for women seeking asylum in Western countries.

All of the contributions to this volume problematize state and nation, though it is the latter that emerges from these contributions as the most damaging in terms of women's identity. The construction of the nation as a natural entity seems inevitably to depend for its continuance on women, but their function within this scheme is reproductive, both physically and in transmitting the values of the nation to new generations (Jacobson, Maitse, Mukta). While the nation seems to constitute an unequivocal danger to women, the state seems redeemable for some. Macaulay on Brazil and Howell on China chronicle the attempts of women to work through the state. In the first case, Macaulay discusses the attempts of women's NGOs to pressurise government at local and national level to respond to violence against women, resulting, for example, in the creation of women's police stations. Howell considers the work of the All-China Women's Federation, which represents women's issues. In each case, while progress has been achieved, the authors conclude that the constraints of operating within traditional state structures make such progress extremely slow.

What emerges clearly from this collection of very different voices is the continuing need to embrace a radical agenda.

Liza Schuster

doi: $10.1057 /$ palgrave.fr. 9400093

\title{
Saving Bernice: battered women, welfare and poverty
}

Jody Raphael; Northeastern University Press, Boston, MA 2000, £14.50 pbk, ISBN 1-55553438-4, £39.00 hbk, ISBN 1-55553-439-2, 184pp

This book looks at the impact of domestic violence on mothers attending welfare to work programmes in the US. By focussing on the story of one African-American mother on welfare - Bernice, Jody Raphael sets out to challenge a number of received wisdoms about mothers living on welfare, domestic violence and poverty, and to cover a range of connected issues. She argues that many women in receipt of welfare payments who had previously been viewed as 'single' mothers do in fact have partners, and suggests that US survey evidence shows that between $20 \%$ and 
$30 \%$ of mothers on welfare are victims of domestic violence. She indicates that the fact that so many women on welfare were already involved in violent relationships was not realized until the welfare to work policy for 'lone' mothers was implemented. It was then recognized that domestic violence was preventing a large number of women from attending the programmes.

She contends that far from seeking alternatives to the nuclear family as has been suggested in feminist theory, some women on welfare may seek to recreate nuclear family relationships and traditional sex roles. Drawing on Bernice's reflections of her adolescent experience and Beth Ritchies' research (1996) on poor AfricanAmerican women's entrapment in abusive relationships, she suggests that the nuclear family can represent an ideal of success for teenage women growing up in families where they may have experienced extreme sexual violence and poverty, and can serve to bind them further into violent relationships.

She describes how welfare to work programmes can function as a means to assist women escaping from such relationships, but these can be blocked by the violent and harassing behaviour of partners who fear that once women get jobs it will make it easier for them to leave. She outlines the devious and extreme measures that such partners will take to prevent mothers from getting educational qualifications and jobs, in order to maintain their dominance and control and to stop them escaping. Such measures include; tearing up educational assignments, deliberately bruising women on the face so that they are ashamed to turn up at classes or work; stalking; kidnapping women and threatening or harassing employers to prevent them from giving women jobs. She also illuminates the difficulties and discrimination abused women may face when they do finally enter employment, and how employers may dismiss them, because harassment from their partners interferes with the smooth running of the workplace.

It is this aspect of the book which I find most illuminating since it develops further insights into women's diverse experiences of domestic violence and its impact, as well as the varied ways it can be used to exert economic control over women in different contexts. It also highlights the measures that are needed within public policy to protect women. For example Raphael suggests that welfare to work programmes need to screen for domestic violence and should not penalise mothers with loss of benefits when they are prevented from attending because of their partners' abuse.

However there are aspects which I find problematic, confusing and contradictory. For example, on the one hand Raphael sets out to challenge universalizing and often white middle class feminist assumptions about mothers on welfare and I think she succeeds in doing this. On the other, she also puts forward universalizing theories of her own. For example she argues that one of the main causes of domestic violence in both black and white heterosexual relationships in low income families, is men's economic jealousy of women and their perceptions of failing 
to be 'real men,' by not fulfilling the 'masculine' breadwinner role. She suggests that this explains the considerable over-representation of domestic violence in lowincome families in the US statistics, and contends that domestic violence could be prevented by eliminating male unemployment and employment discrimination against black men. But this thesis contradicts evidence she puts forward in other parts of the book and is not borne out by the vast amount of survey research on domestic violence in the US as well as in many other countries (see for example Davies, 1994; Gelles, 1997). This is not to deny that some men's domestic violence may be exacerbated by unemployment but to recognize that is not a sufficient explanation in itself.

Another problematic area is represented in her explanation of the causes of poverty and her focus on individualistic solutions. In Raphael's view, poverty is largely seen as a problem of 'social exclusion' and 'welfare dependency' and there appears to be little recognition of any structural causes. The solution is therefore to enable mothers to get off welfare, even though this may be into low-paid work, where their income can be even lower than state benefits. Despite this, she argues that women on welfare who experience domestic violence need to work, because this overcomes their isolation and develops a sense of autonomy, self-worth and achievement. While this may be true for some women, it is not necessarily a solution to the collective problems of gendered poverty and women's low pay, which are related far more to the needs of global capitalism.

In some ways I feel that Raphael tries to do too much with her material in this book and to make too many connections, between the three areas of domestic violence, welfare policy and poverty. Nevertheless she highlights some important issues that are relevant to the 'welfare to work' approaches for 'lone' mothers in the UK, including the need to screen and provide protection for women from domestic violence in these kinds of public policy measures.

Lynne Harne

doi:10.1057/palgrave.fr. 9400094

\section{In our time: memoir of a revolution}

Susan Brownmiller; Aurum Press Ltd, London, 2000, £12.99 Pbk ISBN 1-85410-700-3, 368pp

In Our Time brings alive the late 1960s and 1970s feminist activism within the United States. It is a historical and, at some stages, autobiographical story of the women's second wave revolution. The book is more about the action than about the complex theory that was developed during this period. As is well known, Susan Brownmiller played an important role in this movement. She participated in some 